Meta

Journal des traducteurs

Translators' Journal

\title{
Cultural Differences and Translation
}

\section{Chen Hongwei}

Volume 44, numéro 1, mars 1999

Théorie et pratique de la traduction en Chine

The Theory and Practice of Translation in China

URI : https://id.erudit.org/iderudit/002224ar

DOI : https://doi.org/10.7202/002224ar

Aller au sommaire du numéro

\section{Éditeur(s)}

Les Presses de l'Université de Montréal

\section{ISSN}

0026-0452 (imprimé)

1492-1421 (numérique)

Découvrir la revue

\section{Citer cet article}

Hongwei, C. (1999). Cultural Differences and Translation. Meta, 44(1), 121-132. https://doi.org/10.7202/002224ar

\section{Résumé de l'article}

Cet article traite de l'influence des différences culturelles en traduction à un fait de communication inter-culturel. Peu importe la complexité d'une culture, elle peut être divisée en gros en trois catégories : culture matérielle, institutionnelle et mentale. Lalangue relève de la culture institutionnelle dont la formation et la performance sont liéesintimement à la culture mentale. $\mathrm{Ce}$ sont les différences de culture mentale qui mènentaux différences de langue en traduction. Cet article étudie non seulement les différencesentre le chinois et l'anglais résultant des cultures mentales respectives, se manifestantprincipalement par l'imgae et la fonction, l'intégrité et l'individualisme, le caché et leconnu, la pensée et la forme, mais procure également des méthodes efficaces pourrésoudre les problèmes liés dans la culture en traduction du chinois à l'anglais. 


\title{
Cultural Differences and Translation
}

\author{
chen hongwei \\ Central China Normal University, \\ Wuhan, China
}

\begin{abstract}
RÉSUMÉ
Cet article traite de l'influence des différences culturelles en traduction - un fait de communication inter-culturel. Peu importe la complexité d'une culture, elle peut être divisée en gros en trois catégories: culture matérielle, institutionnelle et mentale. La langue relève de la culture institutionnelle dont la formation et la performance sont liées intimement à la culture mentale. Ce sont les différences de culture mentale qui mènent aux différences de langue en traduction. Cet article étudie non seulement les différences entre le chinois et l'anglais résultant des cultures mentales respectives, se manifestant principalement par l'imgae et la fonction, l'intégrité et l'individualisme, le caché et le connu, la pensée et la forme, mais procure également des méthodes efficaces pour résoudre les problèmes liés dans la culture en traduction du chinois à l'anglais.
\end{abstract}

\section{ABSTRACT}

This article discusses the influence of cultural differences on translation-a cross-cultural communication event. However complex a culture is, it can roughly be divided into three categories: material culture, institutional culture and mental culture. Language belongs to institutional culture, which is closely related to mental culture in formation and performance. Differences in mental culture are what produce the differences in languages involved in translation. The article first examines the differences between Chinese and English arising from their respective mental culture, which are mainly manifested in image and function, integrity and individuality, covertness and overtness, thought and form. It then further provides effective methods to solve culture-bound problems in translation from Chinese into English.

Culture is an extremely complex concept and an enormous subject. It embraces almost everything in the world, whether material or spiritual. But however complex, culture can roughly be divided into three categories: material culture, which refers to all the products of manufacture, institutional culture which refers to various systems and the theories that support them, such as social systems, religious systems, ritual systems, educational systems, kinship systems and language; and mental culture, which refers to people's mentality and behaviours, their thought patterns, beliefs, conceptions of value, aesthetic tastes.

Language, which possesses all the features of culture, belongs to institutional culture. Like all other aspects of culture, language is not inherited but acquired and shared by a whole society; like all other aspects of institutional culture, language is conventional and governed by rules which are acknowledged and observed by all members of society. Language mirrors other parts of culture, supports them, spreads them and helps to develop others. This special feature of language distinguishes it from all other facets of culture and makes it crucially important for the transfer of 
culture. It is no exaggeration to say that language is the life-blood of culture and that culture is the track along which language forms and develops.

The formation and development of all aspects of a culture are closely related to one another, and language is no exception. A careful study of the meanings of words and how these change demonstrates how material culture, institutional culture and mental culture influence the formation and development of language. 窗 originally meant "an opening in the wall or roof of a building, etc. to let in light and air." After a period of rapid economic growth in China, it came to mean "a thing, a place or department which can help people acquire information." 世界之窗 (window on the world) is a bimonthly magazine which caters to Chinese people's thirst to know more about the science, technology, literature and cultural heritage of other countries. 意思 originally refered to the meaning of a word (意义), then extended to mean the implication of words, sentences or discourses (含义), as well as the intention of a person seeking to express gratitude to a benefactor with a gift (心意). In 这点小意思请你收下 (please accept this little gift as a token of my appreciation), 意思 refers to the gift. It is used here as euphemism of 礼物, which could help the recipient save face, given that in China politeness is everything.

Words used in Chinese to address people are closely related to Chinese social life. In China, it is considered polite to address one's elders, superiors or people of importance by their titles, such as 杨老师 (Teacher Yang)，李校长 (President Li) and 张经理 ( $M$ anager Zhang), and family members by their relation, such as 王叔叔 (Uncle Wang)，徐大妈 (Aunt Xu) and 周爷爷 (Grandpa Zhou). These honorifics are troublesome for English-speaking people communicating with Chinese, because Teacher Yang sounds awkward, Aunt Xu may well be a neighbour of the speaker's and Grandpa Zhou is likely not a family member at all. These expressions of respect serve only to demonstrate a very natural tendency among Chinese to use polite terms.

Chinese chengyu (成语), which approximate English idioms, are the gems of the rich Chinese cultural heritage. They originate from other, alien cultures. For instance, 三生有幸 (to consider oneself most fortunate, to make somebody's acquaintance, etc.) and 一尘不染 (spotless) were taken from Buddhism, 灵丹妙药 (miraculous cure) and 回光返照 (momentary recovery of consciousness just before death; a sudden spurt of activity prior to collapse) from Taoism, 妙手回春 (of a doctor) to effect a miraculous cure and bring the dying back to life) and 对症下药 (to suit the medicine to the illness, to suit the remedy to the cause) come from traditional Chinese medicine, 揠苗助长 (to try to help shoots grow by pulling them up-spoil things through excessive enthusiasm) and 五十步笑百步 (one who retreats 50 paces mocks one who retreats 100; the pot calling the kettle black) from classical works. H aving been customarily used for ages in terse terms and with incisive meanings, the Chinese chengyu carry more historical colour and literary allusions than do English idioms, features that have made chengyu very popular.

Every component of language- phonetics, vocabulary and grammar-is the product of cultural development. Grammar, which is essential for gaining control over language, is a triumph of abstract thought, which is influenced by the ecological environment and social factors. People speaking Indo-European languages long ago inhabited dry plains and sea-battered shores, constantly exposed to fierce and everchanging elements of nature. The uncertainty and unpredictability of the elements impelled people to regard nature calmly and objectively as part of their struggle for 
survival. Nature existed as object in opposition to man, who developed the habit of observing, analyzing and learning about nature in order to bring it under control. This opposition between man and nature laid the cornerstone of Western culture which flourished through scientific observation by analytic minds seeking reason, freedom and individuality. This defining feature of Western culture is fully demonstrated in Indo-European languages, especially English, which is a partially synthetic and partially analytic language characterized by overtness in grammar, hypotaxis in syntax, comparatively free word order and flexible word formation.

In contrast, the Chinese who lived in the north temperate zone of the fertile EastAsian continent seemed to be favoured by nature. They were less threatened by the elements and were content to live in a harmonious ecological environment. Their semi-closed geographical conditions and natural agricultural economy cultivated an outlook of being one with nature. This belief gave rise to their simple philosophy of Man's Unity with Heaven, which forms the basis of the Chinese dialectical thought pattern, and emphasizes intuition gained by experience, the concept of the oneness of subject and object, a strong ethical consciousness, and a practical outlook on a simple life. Chinese, as an analytic language, mirrors the psychological characteristics of the Chinese people through parataxis and simplicity in grammar; form is often neglected, coherence is emphasized, and understanding the meaning of a word and its relation to other words is largely dependent on context, or to put it exactly, on one's intuition.

From the analysis above, we can see that language as an institutional facet of culture is closely related to and strongly influenced by other facets of culture, and by mental culture in particular. It is primarily the differences in mental culture between Chinese- and English-speaking people that lead to the differences between the Chinese and English languages. Therefore it is highly revelatory to study the linguistic manifestations of differences in these two mental cultures and, in doing so, we hope to find ways to tackle the culture-bound problems that arise in translation from Chinese into English.

\section{IMAGE AND FUNCTION}

Chinese is imageable because the Chinese emphasizes intuition and images; English is functional because of the Indo-European emphasis on reason and logic.

Chinese is written with characters (also called ideograms), which, in their earliest form, were pictures of things or ideas. Chinese characters in their present, highly developed form, are not a system of picture-writing but a complex means of conveying ideas vividly through images. For instance, $人$ (man) is exactly the image of a man standing with legs parted, 雨 (rain) has four dot strokes symbolizing raindrops, 伞 (umbrella) is shaped like an open umbrella. 日 (sun) and 月 (moon) resemble the sun $(\odot)$ and the moon $(囚)$ in the sky. 日 and 月 combine to give 明 (brightness). 从 (to follow) very vividly depicts one man following another. The meaning of some Chinese words can be understood directly by their visual presentation, such as 短发 (shingle; bobbed hair)，假发 (wig)，硬币(coin)，纸 (note, bill)，回形针 (paper clip), 高根鞋 (stilettos; high-heeled shoes), 短袜 (socks), 无袖外衣 (tabard), 斗蓬式大衣 (poncho-style coat), and 露被装 (halter top). 百襀裙 (pleated skirt) refers to a skirt with many pleats (not necessarily one hundred); 连衣裙 (overall 
skirt) is a piece of clothing that combines a skirt and a blouse. 橡皮奶头 is a nippleshaped rubber object without holes; when a baby cries, you give it 橡皮奶头 to suck so that it feels comforted and stays quiet. The English word "dummy" is an exact equivalent. Many Chinese words are very vividly presented in images, shapes and qualities; their English translation can often only convey their meaning and function in the source text (ST) without preserving the imagery involved.

Images are frequently employed in Chinese as metaphors for abstract ideas or to express sentiments and ambitions. 虫食 (to nibble) likens gradual aggression and occupation to the way silkworms eat mulberry leaves-slowly taking small bites from the leaves. 手忙脚乱 vividly describes a person doing something in a rush. The compound depicts a general flurry of activity without specific reference to 手 and 脚. In 失之交臂 (to just miss a person or a golden opportunity), 交臂 means the two persons are so close to each other that their arms almost touch. In the translation of these two chengyu the meanings may be completely preserved but the images of 手, 脚 and 臂 are lost. 势如破竹 compares splitting bamboo to successive victories won without difficulty. It could be translated in English as "with irresistible force," "like splitting bamboo" or "like a hot knife cutting through butter;" this last option borrows an image from Western culture that has similar connotative meaning. 如日中天 is the description of one who is at the apex of his power or career, just like the sun at high noon. Since both Chinese and English share this cultural phenomenon, a literal translation "like the sun at high noon" or a liberal translation "at the apex of one's power, career, etc." would both be good translations.

A large number of measure words also make Chinese vocabulary very imageable; for example，一枝笔 (a pen)，二张报纸 (a newspaper)，一朵花 (a flower)，二把椅子 (a chair)，二面镜子 (a mirror)，二根棍子 (a stick)，二匹马 (a horse)，二㙉灯 (a lamp)，二棵树 (a tree)，二件外套 (a coat)，二块蛋糕 (a cake)，二口锅 (a wok), etc. Their English translations can very accurately convey the meaning and the quantity of the objects described, but can never succeed in reproducing the vividness of the Chinese measure words.

As Chinese is an ideographic writing system and a tonal language, every Chinese character can be regarded as a trinity of pictograph, ideograph and phone. This unique feature makes Chinese very beautiful. It is indeed a great pity that its beauty of image and sound is completely lost when Chinese is translated into English, an alphabetic writing system with words composed of letters that have no symbolic meaning.

\section{INTEGRITY AND INDIVIDUALITY}

Influenced by the traditional Chinese philosophy of Man's Unity with Heaven, the Chinese believe in a harmonious relationship between man and nature, in the unity of man's spirit with nature, and in the continuum between subjective and objective worlds. In Chinese thought patterns, objects are studied from an overall point of view. This thought pattern is constantly reinforced through social life. English-speaking people, like other Westerners, worship individuality, believing that while man lives in nature, he is independent of nature and must struggle with nature to meet his needs. As a result, the English thought pattern is based on scientific and quantitative analysis and strict logical reasoning. The divergence between these two thought patterns gives rise to many of the differences between the two languages. 
The meaning of Chinese words is usually general while the meaning of English words is specific. 摩托车 is used to refer to all types of motorcycle (or motorbike). In English there are other specific terms such as light motorcycle (轻型摩托车), heavy motorcycle (重型摩托车), sidecar motorcycle (带侧边车的摩托车) and touring moped (旅行摩托车). 车 in “车来了!" may refer to a car, a bus, a minibus, a tram, a lorry, a van, a taxi-any means of transportation with two or more wheels. It is possible to distinguish between them in Chinese, but a Chinese person is much more likely to use a general term th than a specific one in daily communication. 车 means "vehicle" in English, but this general term is rarely used by native English speakers except in official or legal discourse. Native English speakers prefer to be more specific in their references to cars, buses, minibuses, trams, lorries, vans, taxis, etc. The development of the automobile industry has meant that many more types of vehicle are available in the West than in China. This phenomenon of material culture is mirrored in the plethora of English terms to describe vehicles: platform truck, medium van, light lorry, light cross-country lorry with all-wheel drive, heavy lorry, three-way tipper, articulated vehicule, motor coach, two-door saloon car, small threedoor car, three door hatchback, four-door saloon car, eight-cylinder limousine with three rows of three abreast seating, convertible, bucket seat buggy, estate car, sporting coupe, etc. Although some of these vehicles, and their names, have entered Chinese life, such as the double-decker bus and limousine, most are still unfamiliar to ordinary Chinese, who therefore continue to designate vehicles generally as th.

专家 is defined in Chinese dictionaries as "a person who has a particular specialty and knows a lot about it; a person who is very skilled at doing something," which is the exact equivalent to "expert" in English. But Chinese are accustomed to calling all those who have come to work in China 专家 whether they are truly knowledgeable in a field, college graduates or simply skilled workers. On the other hand, an English-speaker prefer to use a specific word for each specific circumstance. It is more natural in English to describe Li Zhengdao (李政道) as a physicist, Niu Manjiang (牛满江) as a biologist, and both as scientists, than to call them "experts." Therefore, 专家 should be translated differently according to the expert's particular specialty, such as physicist, biologist, mathematician, historian, economist, engineer, doctor, etc.

笔 is another example. It is quite natural for a Chinese person who wants something to write with to ask “有笔吗?" though more specific words like 元珠笔, 钢笔, 铅笔, 粉笔 are available. The use of 笔 on its own is perfectly normal and satisfactory in Chinese, whereas the use of "writing implement" (笔) in English is not. An English speaker would ask for a ball-point pen, pen, pencil, piece of chalk or another specific kind of "writing implement," rather than asking "Have you got something I can write with?"

Some Chinese words, however, have very specific referents, arising from the influence of the environment and material culture. 大米 is the staple food for Chinese. When it is growing, it is a plant called 稻子 or 稻米 (水稻); having been harvested, it is called 谷子 or 稻谷; once the chaff is removed, it is called 大米, which can be eaten; it is called 米饭 when it is cooked for food and 稻种 when it is employed as seed. All these specific terms can be rendered into one English word: rice.

The Chinese preference for the general is shown not only in Chinese vocabulary, but also in other aspects of the language. Chinese do not much care whether a 
noun is singular or plural, definite or indefinite. Hence, “你有-杯子吗?" can be rendered as:

- Have you got a cup? Have you got cups?

- Have you got the cup? Have you got the cups?

- Have you got any cups? Have you got some cups?

Without a context, it is impossible to judge which translation is correct.

Empty words (虚词) in Chinese have important grammatical functions, but their meanings are fuzzy and vary in different contexts. In the following examples the empty word 啊 bears various meanings which must be translated accordingly.

这杯牛奶你还喝不喝啊? (question)

Are you going to have this cup of milk?

这究竟是怎么回事啊? (surprise)

What on earth is this all about?

啊, 那行。(promise)

Well, that'll do

啊, 原来是你! (with a dragging voice, indicating understanding)

Oh, it's you!

这花多美啊！(admiration)

How beautiful the flower is!

你爸爸说得对啊! (assertion)

What your father said is right indeed!

来啊, 快来啊! (to hurry sb up)

Come on! Come on!

这任务很艰巨啊! (to remind sb of sth)

The task is tough. Don't you know?

过马路要小心啊！(to offer advice)

Be careful when you cross the street!

上衣啊, 裙子啊, 鞋子啊, 还有其他许多东西, 塞了满满一箱子。

(enumeration) Coats, skirts, shoes and many other things filled the whole suitcase.

\section{COVERTNESS AND OVERTNESS}

Chinese grammar is characterized by covertness, just as English grammar is characteristically overt.

The classification of Chinese words is not so distinct as in English. Chinese has only a few suffixes (e.g. 子, 员, 者, etc.) and auxiliaries (e.g. 的, 地, 得, etc.), it has no formal markers indicating word classes, which must therefore be identified through the context and the word's relation to other words. 红 is a verb in 玫瑰红 (rosy color). Even through it can be converted, the form of the word does not change at all, which makes it difficult to distinguish between words of different classes. Chinese verbs have no markers to indicate tense, voice or mood. English, like other IndoEuropean languages, has definite and indefinite articles to mark nouns, inflections to mark tenses, voices and moods, and many suffixes to indicate nouns, adjectives and adverbs. 
The function of Chinese sentence elements is often indistinct. “星期天，天气晴朗” (It's fine on Sunday) is a complete sentence with a clear meaning, but the function of 星期天 is open to dispute. Some consider it adverbial as it indicates the time of a fine day; some regard it as the subject because it begins the sentence and is described by the latter part of the sentence, which reveals the relation between subject and predicate. An English translation of this sentence produces no such uncertainty because the syntactic relationship is crystal clear.

The subjective and objective cases of Chinese nouns and pronouns have the same form. They can only be distinguished by their grammatical function in the sentence. For example, in “他帮助过我” (He has helped me) and “我帮助过他” (I have helped him), 他 as subject has the same form as 他, the object. But "he" and "him" in English are distinct from each other, because English personal pronouns have distinct forms in subjective and objective cases.

The development of a paragraph also reflects this difference between Chinese and English. A Chinese paragraph tends to follow a circular line of development, which is based on inductive thought patterns. Suspense is usually built all the way to the end of the paragraph. An English paragraph follows a more direct line of development. It often begins with a statement of its central idea, something known as a topic sentence, which is followed by a series of subdivisions of the central idea. These subdivisions develop the idea of the topic sentence and prepare for the addition of other ideas in later paragraphs. In other words, the central idea of a paragraph is usually clear at the very beginning and is expanded on through a deductive thought pattern. In translations from Chinese to English, this syntactic feature cannot be altered for fear that the texture of the ST might be broken. This might explain why English versions of Chinese literature often read a bit unnaturally.

Indirectness is a feature of good Chinese writing, which might have something to do with the reserved character of the Chinese people. The following quotation can serve as an example.

$$
\text { 笑 }
$$

冰心

雨声渐渐的住了, 窗帘后隐隐的透进清光来。推开窗户一看, 呀! 凉云散了, 树叶 上的残滴，映著月儿，好似莹光千点，闪闪㷧㷧的动着。一真没想到苦雨孤灯之后， 会有这么一幅清美的图画!

凭窗站了一会儿, 微微的觉得凉意侵人。转过身来, 忽然眼花缭乱, 屋子里的别的 东西, 都隐在光云里; 一片幽辉, 只浸着墙上画中的安琪儿。一这白衣的安琪儿, 抱着花儿，扬着翅儿，向着我微微的笑.

As the rain gradually ceased to patter, a glimmer of light began to filter into the room through the window curtain. I opened the window and looked out. Ah, the rain clouds had vanished and the remaining raindrops on the tree leaves glistened tremulously under the moonlight like myriads of fireflies. To think that there should appear before my eyes such a beautiful sight after the miserable rain on a lonely evening!

Standing at the window for a while, I felt a bit chilly. As I turned round, my eyes suddenly dazzled before the bright light and could not see things distinctly. Everything in the room was blurred by a haze of light except the angel in a picture on the wall. The angel in white was smiling on me with a bunch of flowers in his arms, his wings flapping. (Bing Xin, Smile, Translated by Zhang Peiji) 
These are the first two paragraphs of a text written by the famous Chinese writer Bing Xin. The story is short, with only 649 characters, and the thematic character 笑 is the 175th character, appearing only at the end of the second paragraph. The author first describes the cessation of the rain, the moonlight filtering into the room, the beautiful view outside after the rain, and the chill she felt standing by the window. Then, very naturally, she turns to describe the things in the room, which is bathed by the haze of moonlight. Her description of the angel follows this sequence: first the white he wears, then the flowers he carries in his arms and his flapping wings, and at last, his smile. The reader moves along with the author from the room to the outside and back to the room. The description of the small room proceeds from far to near, from the ceiling to the floor, from the wall to the angel whose smiling face is at last highlighted. The reader is led through a long zigzagging hallways before the reason for his visit appears. This implicitness is usually copied in English versions, but may not be appreciated by English-speaking readers who are used to more explicit writing.

\section{A UNIQUE CHINESE EMPHASIS ON BEAUTY THROUGH BALANCE}

Influenced by the philosophical idea of the Golden M ean (or Central Harmony), the Chinese developed their peculiar aesthetic values, one of which is a unique emphasis on the beauty of balance. For example, antithesis is an important figure of speech in both Chinese and English; it emphasizes a contrast by presenting contradictory or similar ideas by using two or more words or sentences in sharp juxtaposition. But antithesis is much more prevalent in Chinese poetry, folk songs, proverbs and proverbial expressions than it is in most English forms.

e.g. 人无千日好，花无百日红。(proverb)

Man cannot always be fortunate; flowers do not last forever (Tr. Li Dingkun)

满招损，谦受益。(Book of songs)

Haughtiness invites losses while modesty brings profits (Tr. Li Dingkun)

The effect of contrast is achieved in both source text (ST) and target text (TT) by means of antithesis. 好 and 红 in this context bear connotative meanings which are properly translated. "While" in the second sentence connects two contradictory ideas and emphasizes the contrast. This amplification of words is often found even in the translation of classical Chinese poems.

登鹳雀楼

王之涣

白日依山尽，黄河人海流。

欲穷千里目, 更上一层楼。

The white sun sets behind mountains,

The Yellow River flows into the sea.

Go further up one flight of stairs,

And you'll widen your view a thousand li

(Wang Zhihuan, M ounting the Stock Tower, Tr. Li Dingkun) 
The first two lines of the ST are sharply juxtaposed with co-ordinate ideas presented by 黄河 and 白日, 人 and 依, 海, and 山, 流 and 尽. So are the first two lines of the TT. The last two lines of the ST are made cohesive by the implied relationship between condition and result. "And" is thus amplified to reproduce this relationship and "You" to make the fourth line a complete sentence. The TT seems to have changed the form of the antithesis somewhat, but this change is necessary in order to preserve all the meanings of the ST.

The formation of many Chinese four-character compounds with co-ordinate relations also reveals this aesthetic value of balance. Balance is so carefully maintained in these four-character compounds that meaning is often repeated. For example, 天造地设 consists of two parts, 天造 and 地设. 地设 actually repeats the meaning of 天造 in a similar form. This formation, which can be found in 天涯海角, 十拿九稳, 年深月久, 繁荣昌盛 and many others, serves to make compounds balanced in both form and sound with an emphasis on meaning. In translation, it suffices to translate the meaning of one part of the compound in order to avoid redundancy. The five compounds above can be translated, respectively, into be created by nature (ideal), the ends of the earth (the most remote corners of the earth), practically certain, as the years go by and prosperity. This method can only be used when a co-ordinate relationship exists, and it is not the only method available. As to other kinds of four-character compounds with modifying relationships or subject-predicate relationships, a careful analysis of the exact relationship should be made before a translation method is selected.

\section{THOUGHT AND FORM}

To the Chinese, thought is more important than form. What they care about is the conveyance of meaning; form is secondary. English-speakers place more value on form, which is regarded as the product of scientific reasoning and analysis. As a result, Chinese is a topic-dominated language while English is a subject-dominated language. A Chinese sentence revolves around a thought pivot, while English sentences rely on a form-pivot (or subject-predicate pivot). Therefore, the subject of a sentence is not as important in Chinese as it is in English. In Chinese, the subject is no more than the topic discussed; it can be a noun or a word of an other class; any word that begins a sentence (thematic position) can be regarded as the subject be cause anything can be a topic. In English, the subject is the indispensable element of a sentence; it should be nominal and has a decisive grammatical function-even a slight change in the subject may affect the whole sentence. Hence, when translating from Chinese into English, it is very important to select a suitable subject for the establishment of the subject-predicate mechanism - the kernel of the translated sentence. Sometimes the subject should be amplified; other times it should be determined by the context, the logical relationship, or the need for concordance between subject and predicate. The translations of the following sentences provide some examples.

一边走着，似乎道旁有一个孩子，抱着一堆灿白的东西。驴儿过去了，无意中回头 一看一他抱着花儿, 赤着脚儿, 向着我微微的笑。 
As I passed along, I somewhat sensed the presence of a child by the roadside carrying something snow white in his arms. After the donkey had gone by, I happened to look back and saw the child, who was barefoot, looking at me smilingly with a bunch of flowers in his arms. (Tr. Zhang Peiji)

The Chinese thought pattern makes it possible to apprehend the subjects of 一边走着, (感到) 道旁有一个孩子, 无意中回头一看 immediately. In the English translation, "I" must be added three times in order for English readers to understand who is doing the action and for the sentences to be complete.

（2）公费吃喝是群众反映强烈的不正之风之一。

\section{( 伊丽: 《清除腐败》《现代中国》1994 年第 2 期)}

Sumptuous banquets, financed by public money, have long been the bane of Chinese society. (China Today, Feb. 1994)

In present-day China, 公费吃喝 does not literally mean “to eat and drink at public expense", but bears a connotative meaning that is aptly rendered by the subject "banquets" and the modifiers "sumptuous" and "financed by public money." With "banquets" as subject, "ominous trend," which would be the exact equivalent of 不正之风 in this context, cannot be used as a subject-complement, as it would create an improper concordance between subject and predicate. "Sumptuous banquets, financed by public money" is a typical manifestation of corruption in China, at which large sums of money are wasted, principles are abandoned and laws are disregarded. They have, in fact, almost become the bane of society. The TT is faithful to the ST as it employs a proper subject and correct subject-predicate agreement.

（3）不要有了新亲，把旧亲忘个干净！这种没良心的人我见得多了

\section{( 钱钟书: 《围城》)}

... Once you have new relatives, don't forget the old ones. I've seen too many such ungrateful people. (Tr. Jeanne Kelly \& Nathan K. Mao)

The first sentence of the ST is subjectless. It is a piece of advice with an imperative function. Hence the "You" (listener) is added. "I" is selected as the subject of the second sentence to make the version natural.

（4）以后这四个月里的事，从上海撤退到南京陷落，历史该如洛高（Fr.von Logan）

所说，把刺刀磨尖当笔，蘸鲜血当墨水，写在敌人的皮肤上当纸。

\section{( 钱钟书: 《围城》)}

What happened during the next four months, from the retreat from Shanghai to the fall of Nanking, should be recorded in history, as Fridrich von Longan put it, with a bayonet dipped in the ink of fresh blood upon the paper made from the skin of the enemy. ( $T r$. Jeanue Kelly \& Nathan K. M ao)

事 is the topic of the ST, refering to enevything that took place in those four months during the Anti-Japanese War. In those tumultuous days, many things, big and small, happened. "Event" as subject seems too big, "incident" too small, and "episode" or "occurrence" lack the dynamism of the subject clause introduced by "what." The relationship in the sentence with 把 is very adequately reproduced, making the translation vivid and fluid. 
A Chinese sentence does not require concordance between subject and predicate, whereas English sentences do. Chinese syntax is characterized by parataxis; English syntax by hypotaxis. Connective words are usually omitted in Chinese and should be amplified in the translation into English. These differences between the two languages, coupled with the fact that sentence-making and composition are usually determined by the author's intuition or imagination mean that the translator has to follow the author's train of thought, and understand the various meanings and relationships in the ST in order to produce a faithful translation. For example:

一眼望去, 疏疏的林, 淡淡的月, 祄着蓝蓝的天, 颇像荒江野渡光景; 那边呢? 郁 丛丛的, 阴森森的, 又似乎藏着无边的黑暗: 令人不相信那是繁华的秦淮河了。

\section{( 朱自清: 《浆声灯影里的秦淮河》)}

As one looked into the distance, the sparse trees and pale moon set off by the blue sky offered a view like that at a deserted ferry on a desolated river. Further yonder, the gloom seemed to hide boundless darkness, which one could hardly believe was still part of the busy Qinhui River. (Tr. Hu Shiguang)

The ST is like a Chinese ink wash print. The first part of the sentence is loose in form with 疏疏的林, 淡淡的月 and 衬着蓝蓝的天 as the logical subject of 颇像荒江野 渡光景. Adjustments should of course be made to render the version cohesive. Here, "set off by the blue sky" connects the sky and the moon, "offered" and "view" are amplified to achieve cohesion, "at a deserted ferry on a desolate river" conveys the precise relationship between 荒江 and 野渡. The artistic concept of the ST is thus vividly reproduced.

Syntax is a very close representation of style. A translator should be aware of this point and try to keep syntactic differences to a minimum if he or she expects to produce a translation close in style to the ST.

\section{CONCLUSION}

This contrastive study of Chinese and English focuses on their differences, and we can conclude from it that differences in language arise from differences in mental culture. While translation is obviously a transfer of language, it is also a transfer of mental culture. The process of translation is actually one of mental transfer accomplished through language. It is therefore important for a translator to conduct contrastive studies in mental culture and acquire a profound insight into the essence of translation in order to solve culture-bound translation problems effectively.

\section{REFERENCES}

Chen, Hongwei (1986): "Cultural Barriers in Translation (with special reference to Chinese and English)", Building Bridges. Proceedings of the 27th Annual Conference of the Ameriacn Translators Association, Learned Information, Inc.

- - (1995): "On the Importance of Pragmatics to the Teaching of Translation”, The First International Symposium on Foreign Language Teaching Proceedings, Wuhan, Huazhong University of Science and Technology.

Nida, Eugene A. \& William D. Reybur n (1981): M eaning Across Cultures, Orbis Books.

Bander , Robert G. (1978): American English Rhetoric, Holt, Rinehart and Winston. 
北京外国语学院英语系词典组编, 《汉英成语词典》, 商务印书馆, 1982 年

[Dictionary-compiling Group (1982): A Chinese-English Dictionary of Idioms, Beijing, Commercial Press.]

陈宏薇编著， 《新实用汉译英教程》，湖北教育出版社，1996 年

[Chen, Hongwei (1996): A New Practical Textbook of Translation from Chinese into English, Wuhan, Hubei Education Press.]

邓炎昌、刘润清, 《语言与文化》, 外语教学与研究出版社, 1989 年

[Deng, Yanchang \& Liu, Rungqing (1989): Language and Culture, Beijing, Foreign Language Teaching and Research Press.]

李定坤, 《汉英辞格对比与翻译》, 华中师范大学出版社, 1994 年

[Li, Dingkun (1994): Chinese and English Figures of Speech-Comparison and Translation, Wuhan, Central China Normal University Press.]

刘重德主编, 《英汉语比较研究》, 湖南科学技术出版社, 1994 年

[Liu, Zhongde (Ed.) (1994): Comparative Chinese-English Studies, Changsha, Hunan Science and Technology Press.]

刘密庆, 《汉英对比研究与翻译》, 江西教育出版社, 1991 年

[Liu, Miqing (1991): CE-EC Contrastive Studies and Translation, Nanchang, Jiangxi Educational Publishing House.]

邢福义主编, 《文化语言学》, 湖北教育出版社, 1990 年

[Xing, Fuyi et al. (1990): Linguistics: A Cultural Perspective, Wuhan, Hubei Education Press.]

许余龙, 《对比语言学》, 上海教育出版社, 1992 年

[Xu, Yulong (1992): A General Survey of Contrastive Linguistics, Shanghai, Shanghai Foreign Language Education Press.] 